\title{
TIESNEŠU PAŠPĀRVALDES INSTITŪCIJU LOMA VARAS DALİ̌̌ANAS MEHĀNISMĀ
}

\section{ROLE OF JUDICIAL SELF-GOVERNANCE BODIES IN THE MECHANISM OF SEPARATION OF POWERS}

\author{
Solvita Harbaceviča, LL.M. \\ Latvijas Universitātes Juridiskās fakultātes \\ Tiesību teorijas un vēstures zinātṇu katedras doktorante
}

\section{Summary}

There are three judicial self-governance bodies in Latvia - Judicial Qualification Board, Judicial Disciplinary Board and Judicial Ethics Commission. Together with the Judicial Council, they form a network tasked with ensuring the compliance with professional and ethical standards required for performance of task entrusted to the judiciary in the mechanism of separation of powers in a democratic state. The author argues that self-scrutiny by the judiciary is a precondition for its independence. A further increase of depth and quality of self-policing can be achieved through institutional strengthening of the said bodies.

Atslēgvārdi: varas dalī̌̌ana, tiesu varas neatkarība, tiesnešu pašpārvaldes institūcijas, Tieslietu padome

Keywords: separation of powers, independence of judiciary, judicial self-governance bodies, Judicial Council

\section{Ievads}

Tiesu varas neatkarība pēdējos gados ir plaši apspriests temats gan Latvijā, gan Eiropas Savienībā. Pieaugot populisma tendencēm politiskajā spektrā, tieši tiesu vara ir visapdraudētākais valsts varas mehānisma zobrats. Īpaši būtisks šādas apdraudētības risks ir valstīs, kur sabiedrības uzticēšanās valsts varas struktūrām ir zema. Šāda situācija visbiežāk noved nevis pie vienotas varas atzaru stratēgijas sava darba uzlabošanai, bet pie sabiedriskajā telpā konkurējošas kritiskas retorikas, kas kopumā neveicina valsts mērķu sasniegšanu.

Tādēl gan likumdevējam, gan izpildvarai, gan tiesu varai ir svarīgi pievērsties pašrefleksijai. Jau pašu atbildības, atskaites mehānismu esamība palīdz nostiprināt tiesu varas leǵitimitāti. ${ }^{1}$ Pašanalīze, sistēmiska domāšana un izaugsmes vēlme ìpaši svarīga ir tiesu varai, kas kopš Monteskjē laikiem un arī pašreizējā

1 Košar D. Perils of Judicial self government in transitional societies. Cambridge University Press, 2016, p. 63. 
tās stāvoklī Latvijā objektīvi ir vājākā no varām un daudzos tās darbības aspektos atkarīga gan no likumdevēja, gan no izpildvaras.

Viss, ko savai nostiprināšanai izdarīs pati tiesu vara, kalpos ne vien tās pašas izaugsmei, bet arī valsts varas iekšèjam lìdzsvaram un varas dalîšanas mehānisma optimālai funkcionēšanai.

Satversmes tiesa pēdējā no saviem "tiesnešu algu" sērijas spriedumiem atgādināja, ka "[t]iesu vara ir viens no trim valsts varas atzariem atbilstoši no pamatnormas atvasinātajam un Satversmes 1. panta tvērumā ietilpstošajam varas dalī̌sanas principam. Saskaṇā ar Satversmes 82. pantu tiesu sistēma ir konstitucionāls orgāns, savukārt tiesneši ir šā konstitucionālā orgāna amatpersonas, kas īsteno tiesas spriešanu valstī. Ikviens tiesnesis (ja lieta tiek izspriesta vienpersoniski) vai tiesnešu kolēgija (ja lieta tiek izspriesta koleǵiāli), kas veido tiesas sastāvu, savā amata darbībā īsteno tiesu varu. Tādējādi ikviens tiesnesis, spriežot tiesu, darbojas arī kā izpildvaras un likumdevējvaras atsvars no valsts varas dalīšanas principa izrietošajā lìdzsvara un atsvara sistēmā”. ${ }^{2}$

Tiesu varas neatkarības princips visupirms nozīmē tiesas neatkarības garantijas tiesas spriešanas laikā. Šìs garantijas ir konstitucionālas, tālāk likumos izvērstas. Tomēr, kā norāda Satversmes tiesa, konstitucionāla funkcija ir veicama katram tiesnesim.

Tādēḷ tiesneša neatkarībai ir ne vien objektīvā, bet arī subjektīvā puse. Tikai tiesnesis, kas ir pietiekami kvalificēts, izprot profesionālās ètikas principus (gan attiecībā uz savu rīcību, gan uz to, kāda rīcība ir ètiska, piel̦aujama pret viṇu) un ar cieņu izturas pret sava amata statusu, var būt patiesi neatkarīgs.

Tiesu vara modernā sabiedrībā ir sarežg̀ìts institucionāls mehānisms, kura optimālai funkcionēšanai ir nepieciešami vienoti ètikas, profesionālie un disciplinas standarti.

Analizējot tiesneša, kas, kā to atgādināja Satversmes tiesa, arī individuāli veic konstitucionālu funkciju, atbildību (accountability nozīmē), to var iedalìt piecās formās ${ }^{3}$ - juridiskā (legal), kas tiek realizēta, piemēram, caur pārsūdzību, institucionālā, kas saistīta ar karjeras virzību, profesionālā - kolēǵu veikta zināšanu pārbaude, vadības (managerial) pārbaude, kas saistās ar darba organizāciju un efektivitātes standartiem, un sabiedrības priekšā (societal), kas tiek nodrošināta caur informācijas pieejamību un tieslietu sistēmas caurredzamību.

Šo tiesneša darba aspektu analīze ir tiesnešu pašpārvaldes institūciju - Tiesnešu kvalifikācijas kolēgijas, Tiesnešu disciplinārkolēgijas un Tiesnešu ètikas komisijas - kompetencē. Ir svarīgi apzināties to lomu - ne vien to individuālajos, uz katra tiesneša karjeru attiecināmajos lēmumos, bet arī kopējo, sistēmisko.

\section{Tiesnešu pašpārvaldes institūcijas}

\section{Tiesnešu kvalifikācijas kolēgiija}

Tiesnešu kvalifikācijas kolēgija (turpmāk - TKK) ir tiesnešu pašpārvaldes institūcija, kura veic tiesnešu profesionālās darbības novērtěšanu. Tās darbību

2 Satversmes tiesas 26.10.2017. spriedums lietā Nr. 2016-31-01.

3 Piana D. Judicial Accountabilities in New Europe: from Rule of Law to Quality of Justice. Routledge, 2016. 
regulē likums "Par tiesu varu” un kolēgijas reglaments, kuru apstiprina Tieslietu padome.

TKK ir visu trīs instanču tiesneši, savukārt sistēmisku informētību par tās darbu nodrošina iespēja tajās piedalīties likumā uzskaitītām amatpersonām. ${ }^{4}$

TKK, kā jau tas izriet no tās nosaukuma, pēc būtības ir profesionālās sagatavotības iekšèjās kontroles mehānisms, ar kura palīdzību pārbauda gan tiesneša amata kandidātus, gan tiesnešus, gan regulāri karjeras gaitā, gan mainot jurisdikciju (piemēram, no administratīvās tiesas uz vispārējo) vai instanci. ${ }^{5}$

Visbūtiskāko TKK darba daḷu veido tiesneša profesionālās darbības kārtējā novērtēšana reizi piecos gados. Kārtējais novērtēšanas cikls ir sācies 2018. gadā, un uz ši raksta pabeigšanas brīdi ir novērtēta vairāk nekā puse Latvijas tiesnešu. Būtisks jauninājums šajā novērtēšanas ciklā izriet arī no nesenajiem grozijumiem TKK reglamentā, ${ }^{6}$ kas l̦auj TKK pozitīva novērtējuma gadījumā izteikt piezīmes par to, kādi tiesneša darba aspekti uzlabojami līdz nākamajai novērtēšanai. Tagad jānodrošina, lai šai informācijai būtu sekas tādā nozīmē, ka tā jāṇem vērā ne vien pašam tiesnesim, bet arī tiesas priekšsēdētājam un Tiesnešu mācību centram, gatavojot mācību programmas un akceptējot tiesnešu dalîbu tajās.

Nākotnē sagaidāms jauninājums TKK darbā būs ārpuskārtas novērtēšana, kas veicama pēc Tiesnešu disciplinārkolēgijas nosūtījuma.

\section{Tiesnešu disciplinārkolēg̣ija}

Tiesnešu disciplinārkolēgija (turpmāk - TDK) ir tiesnešu pašpārvaldes institūcija, kas izskata lietas par visu līmeņu tiesu tiesnešu disciplinārajiem un administrativajiem pārkāpumiem. Tās darbību regulē "Tiesnešu disciplinārās atbildības likums", 7 atsevišḳi likuma "Par tiesu varu" panti un pašas TDK apstiprināts nolikums.

Tiesnesi var saukt pie disciplinārās atbildības par tīšu likuma pārkāpumu tiesas lietas izskatīšanā, darba pienākumu nepildīšanu, necienīgu rīcību un par administratīvu pārkāpumu. Savukārt tiesas nolēmuma atcelšana vai grozī̌sana pati par sevi nav iemesls tam, lai sauktu pie atbildības tiesnesi, kas piedalījies tā pieņemšanā, ja viņš nav piẹ̦āvis tīšu likuma pārkāpumu vai nolaidību. ${ }^{8}$

Lietas izskatīšanu TDK var ierosināt gan visu līmeņu tiesu priekšsēdētāji, ${ }^{9}$ gan Tiesnešu ētikas komisija un arī tieslietu ministrs. ${ }^{10}$

\footnotetext{
${ }^{4}$ Saeimas Juridiskās komisijas priekšsēdētājs, tieslietu ministrs, generālprokurors, Augstākās tiesas priekšsēdētājs vai viṇu pilnvarotas personas, Latvijas Zinātṇu akadēmijas apstiprinātu tiesību zinātṇu ekspertu delegéts pārstāvis, kā arī tiesnešu biedrību pārstāvji. Praksē tās gan ir tikai tieslietu ministra un Augstākās tiesas priekšsēdētāja pilnvarotas personas, kā pēdējā atseviškos gadỉjumos arī šì raksta autore.

${ }^{5}$ Izvērsumu sk.: Vīgants M. Aktualitātes tiesnešu profesionālās darbības novērtēšanā. Augstākās Tiesas Bil̨etens, 2019, Nr. 19, 39.-41. lpp.

6 Saskaņā ar likuma "Par tiesu varu" 89. ${ }^{11}$ panta devīto dalı un 94. panta ceturto daḷu TKK reglamenta jaunā versija apstiprināta ar Tieslietu padomes 12.11.2018. lēmumu Nr. 359. Pieejams: http://www. at.gov.lv/lv/tieslietu-padome/dokumenti.

${ }^{7}$ Latvijas Vēstnesis, 10.11.1994., Nr. 132, konsolidētā versija. Pieejams: https://likumi.lv/doc.php?id= 57677\&version_date=24.11.1994.

8 Tiesnešu disciplinārās atbildības likuma 1. pants.

9 Par savas tiesas tiesnešiem - visos likumā paredzētajos gadījumos, par katras zemākās instances tiesas tiesnesi - vienīgi par tīšu likuma pārkāpumu tiesas lietas izskatīšanā.

10 Par rajona un apgabaltiesu tiesnešiem - visos likumā paredzētajos gadijjumos.
} 
Pēdējo gadu laikā TDK darbu regulējošajos likumos ir veikti vairāki grozījumi. 2017. gadā trīs mēnešu termiņšs soda uzlikšanai pēc disciplinārā vai administratīvā pārkāpuma atklāšanas dienas tika aizstāts ar triju mēnešu termiṇu pēc disciplinārlietas ierosināšanas dienas, atvieglojot sodī̌anas iespēju. Apspriežot šos grozijumus, tika izlemts nemainīt vispārējo divu gadu termiņu soda uzlikšanai pēc pārkāpuma izdarīšanas dienas, tomēr jau šobrīd Saeimā pieņemšanu trešajā lasījumā gaida kārtējais Tiesnešu disciplinārās atbildības likuma grozijjumu projekts, kurā šis termiņš pagarināts no diviem uz četriem gadiem. ${ }^{11}$ Tāpat 2017. gada grozījumi ieviesa lielāku caurspīdīgumu TDK darbā, paredzot, ka, publicējot disciplinārlietā pieṇemto lēmumu, pie atbildỉbas sauktās personas vārds un uzvārds netiek aizsegts. ${ }^{12}$

\section{Tiesnešu ētikas komisija}

Tiesnešu ētikas komisija (turpmāk - TĒK, Komisija) ir koleg̣iāla tiesnešu pašpārvaldes institūcija, kuras kompetencē ir sniegt atzinumus par ètikas normu interpretāciju un pārkāpumiem, kā arī skaidrot tiesnešu ètikas normas. Tās darbỉbu regulē likums "Par tiesu varu" un Tieslietu padomes apstiprināts reglaments. Komisijas kompetencē ir sniegt atzinumus par ètikas normu interpretāciju un pārkāpumiem, skaidrot un analizēt Tiesnešu ètikas kodeksa normas, kā arī konsultēt tiesnešus par tiesnešu ètikas jautājumiem, apkopot atziņas un skaidrojumus par ètikas normu interpretāciju un piemērošanu, apspriest ètikas normu pārkāpumus, izstrādāt Tiesnešu ētikas kodeksa normas, kā arī lemt par disciplinārlietas ierosināšanu.

Šì brī̌a komisijas darba aktualitāte ir jaunā Tiesnešu ètikas kodeksa projekts, kura apstiprināšana gaidāma 2020. gada tiesnešu konferencē. Kodekss balstās uz pieciem kanoniem - neatkarība, godprātỉba un cien,a, objektivitāte, kompetence, atbilstība. ${ }^{13}$ Kanoni un tos detalizējošās normas ir mēraukla, ar kuru tiek samērota katra individuālā tiesneša situācija. Komisijas skaidrojumi, atzinumi un lēmumi, piemērojot Ėtikas kodeksa normas individuālām situācijām, ir publiski pieejami. ${ }^{14}$

Trīs aprakstītās tiesnešu pašpārvaldes institūcijas rūpējas katra par savu tiesneša darbības aspektu, taču to darbā ir vērojama kompetenču saskare. Piemēram, ja TĒK konstatē, ka tiesnesis ir pię̦āvis rupju tiesneša ètikas normu pārkāpumu, tas ir pamats disciplinārlietas ierosināšanai, kurā lēmums pieņemams jau TDK. Līdzīgi disciplinārlietas izskatǐšanas gaitā var tikt secināts, ka pārkāpuma īstais iemesls ir kvalifikācijas problēmas, kas tādā gadỉjumā izvērtējamas TKK ārpuskārtas novērtēšanas formā.

Likums "Par tiesu varu" visai strikti nodala visas trīs pašpārvaldes institūcijas un Tieslietu padomes vēlēto personālsastāvu, nosakot, ka to starpā nav pię̧aujama personāliju pārklāšanās. Tas tomēr nenozīmē, ka tiesnesis, kas pagātnē strādājis vienā no šìm institūcijām, vēlākā periodā nevar strādāt citā. Tāpat minētā kompetenču saskare dod iemeslu savstarpējām konsultācijām par

${ }^{11}$ Likumprojekts Nr. 481/Lp13. Pieejams: https://titania.saeima.lv/LIVS13/saeimalivs13.nsf/webSasaiste? OpenView\&restricttocategory=481/Lp13.

12 Pieejams: https://likumi.lv/ta/id/292027-grozijumi-tiesnesu-disciplinaras-atbildibas-likuma.

13 Tiesnešu ētikas komisijas priekšsēdētājas Allas Šilovas runa 2019. gadā tiesnešu konferencē. Augstākās Tiesas Biḷetens, 2019, Nr. 19, 44. lpp.

14 Pieejams: https://www.tiesas.lv/tiesnesu-etikas-komisijas-sedes. 
sistēmiskiem jautājumiem - piemēram, par Ētikas kodeksa "rupja pārkāpuma" jēdzienisko ietilpību.

\section{Tieslietu padome}

Tieslietu sistēmas paškontroles mehānismu analīze nebūtu pilnīga bez pievēršanās Tieslietu padomei un tās saistībai ar trijām tiesnešu pašpārvaldes institūcijām.

Pirmkārt gan jāatrunā, ka pati Tieslietu padome nav tiesnešu pašpārvaldes institūcija, tās kompetence un personālsastāvs ir plašāks un citādi veidots, iekḷaujot gan politiķus, gan brīvo juridisko profesiju pārstāvjus. Likuma "Par tiesu varu" 89..$^{1}$ pants noteic, ka "Tieslietu padome ir kolegiāla institūcija, kas piedalās tiesu sistēmas politikas un stratēgijas izstrādē, kā arì tiesu sistēmas darba organizācijas pilnveidošanā”.

Savā 2016. gada Ziṇojumā par Tieslietu padomes darba pilnveidošanu Valsts prezidenta izveidotā Tiesiskās vides pilnveides komisija norādīja, ka šāds vispārīgs Tieslietu padomes kompetences definējums liecina par plašas kompetences pieškīrumu Tieslietu padomei un ir pietiekams pamats tam, lai Tieslietu padome varētu īstenot mērḳus, kuru labad tā tika izveidota, proti, nodrošināt tiesu varas efektivitāti un kvalitāti, aizsargāt tiesnešu un tiesu neatkarību un vairot sabiedrïbas uzticību tiesu varai. ${ }^{15}$

Pirms pievēršamies pašreizējās situācijas analīzei, īss Tieslietu padomes izveides konteksts.

Periodā, kad Latvijā sākās diskusijas par Tieslietu padomes izveidošanas nepieciešamību, izpratne par šāda tipa institūciju funkcionālo nozīmi arī Eiropā strauji attīstījās. Kopumā Tieslietu padomes ir salīdzinoši jaunas institūcijas, to rašanās ir saistīta ar Eiropā pagājušā gadsimta otrajā pusē aizvien pieaugošo nozīmi, kas Eiropas Savienībā tika piešķirta tiesu varas neatkarībai.

Cenšoties attīstìt analīzi par optimālo Tieslietu padomes institucionālo modeli un vietu katras valsts, arī Latvijas, konstitucionālajā sistēmā, jāatceras divi faktori, kas to ietekmē.

Pirmkārt, visas Eiropas Savienības valstis jau gadu desmitiem virzās uz atsevišķu nacionālo tiesību sistēmu sektoru konverǵenci. Viens no šìs konverǵences aspektiem ir likumdošanas harmonizācija, kas noved pie tiesību normu tuvināšanas ES kompetencē esošajās tiesību jomās. Lai arī šajā līmenī joprojām esam pieraduši primāri domāt par materiālajām tiesību normām jomās, kas saistītas ar iekšējo tirgu un muitas savienību, harmonizācija skar arī administratīvo un kriminālo atbildību nosakošās tiesību normas (nepieciešamība noteikt sankcijas par ES tiesību pārkāpumiem) un procesuālo likumdošanu. Šie abi aspekti ir saistīti arī ar ES tiesību efektivitāti - tām jābūt vienlīdz viegli izpildāmām ar nacionālo procesuālo normu starpniecību. Procesuālo normu konverǵence notiek arī, ja nepieciešams nodrošināt starptautisko tiesisko sadarbību.

Ja saprotam šo efektivitātes nozīmi mikrolīmenī, individuālās normās un individuālu tiesisko situāciju risinājumos, jāsaprot arī, ka nacionālajām institūcijām, kas nodrošina tiesisko strīdu izškłiršanu, ir jāstrādā atbilstoši noteiktiem

${ }^{15}$ Pieejams: http://at.gov.lv/files/uploads/files/9_Tieslietu_padome/Dokumenti/www_president_lv_ TVPK.pdf. 
kvalitātes standartiem. Attiecībā uz tiesas spriešanu viens no pamatpostulātiem tiesību uz taisnīgu tiesu nodrošināšanā ir neatkarīgas tiesas. Šìs idejas aizstāvībai tiek veidotas Tieslietu padomes. Bet arī pašām Tieslietu padomēm jāatbilst noteiktiem kritērijiem, lai tās varētu efektīvi pildīt savas funkcijas. Šìs prasības nav noteiktas saistošu starptautisku normu formā, bet atrodamas vispārzināmās un respektētās rekomendācijās. Katrai valstij jāsamēro savs izvēlētais modelis ar starptautiski definēto standartu. Piemēram, optimālajā gadījumā (kam ne vienmēr atbilst visu ES dalỉbvalstu praktiskie risinājumi) Tieslietu padomes locekḷu vairākums ir jāveido tiesnešiem, bet vēlams tomēr izvēlēties jauktā sastāva modeli, lai Tieslietu padome nezaudētu savu valstisko lomu un netransformētos, pēc būtības vai sabiedrības uztverē, vien par tiesnešu interešu aizsardzìbas institūciju. ${ }^{16}$

No otras puses, katra tiesību sistēma veidojas un funkcionē konkrētās valsts vēsturiskajā, kultūras un sabiedrības kontekstā. Tādēl arī katra Tieslietu padome ir unikāla un starpvalstu salīdzinājumiem un model̦u analīzei ir vairāk iedvesmas nozīme. Labi darbojošos modeli nevar automātiski pārnest no vienas valsts uz otru, jo katrs no tiem darbojas individuālā checks and balances sistēmā. ${ }^{17}$

Plašākā Eiropas kontekstā tieslietu sistēmas pārvaldības institucionālos model̦us nosacìti iedala Ziemel̦eiropas un Dienvideiropas modelī. Ziemel̦eiropas modelis ir vairāk orientēts uz tiesu sistēmas praktiskās pārvaldes jautājumiem, bet Dienvideiropas modeli raksturo augsts institucionālais statuss un plašas pilnvaras. Tā Francijas, ${ }^{18}$ Itālijas, ${ }^{19}$ arī Spānijas ${ }^{20}$ un Portugāles ${ }^{21}$ Tieslietu padomju statuss ir konstitucionāli nostiprināts. Itālijas padomi ex officio formāli vada Republikas prezidents, savukārt Spānijas un Portugāles - lìdzīgi kā Latvijā - Augstākās tiesas priekšsēdētājs.

Latvijas izvēlētajā institucionālajā modelī Tieslietu padome daudzējādā ziṇā no pirmā acu uzmetiena atgādina noteiktus Dienvideiropas modeḷa aspektus tā plašo sastāvu, ex officio vadỉbu un arī plašo kompetenci. Tomēr daudzi faktori norāda uz to, ka šì līdzība ir tikai virspusēja. Būtiskākie no tiem ir Tieslietu padomes institucionālā kapacitāte, kā arī atsevišķu tās funkciju ierobežotā realizācijas iespēja.

Pievērsīsimies vienam no svarīgākajiem Tieslietu padomes darba aspektiem līdzdalībai tieslietu sistēmu regulējošo normatīvo aktu izstrādē.

Likumdošanas jomā Tieslietu padome sniedz savu viedokli par likumprojektiem, kas ietekmē tiesu varas uzbūves un funkcionēšanas principus.

Tieslietu padomei nav likumdošanas iniciatīvas tiesības, tādēl gadījumos, ja tā uzskata par nepieciešamu izdarìt kādus grozījumus, tā var vērsties pie Tieslietu ministrijas vai Saeimas Juridiskās komisijas.

Savukārt likumdošanas procesā pēdējo gadu laikā plaši pielietota ir prakse, kad Tieslietu ministrija virza likumprojektu nevis parastajā saskaņošanas

\footnotetext{
16 Varas delegéšana tiesnešiem prasa atbildību un atvērtību sabiedrībai, un abi šie aspekti realizējami ar Tieslietu padomju starpniecību. Sk.: Garoupa, Ginsburg. The Compartive Law and Economics of Judicial Councils. University of Illinois, Illinois Law and Economics Research Paper Series, Research Paper No. LE08-036, p. 6. Available at: https://papers.ssrn.com/sol3/papers.cfm?abstract_id=1299887.

17 Fūrmans V. Tieslietu padomes Eiropā: tendences un model̦i. Jurista Vārds, 28.09.2004., Nr. 37 (342).

18 Pieejams: https://www.encj.eu/images/stories/pdf/factsheets/csm_france.pdf.

19 Pieejams: https://www.encj.eu/images/stories/pdf/factsheets/italy_csm.pdf (vispārējā tiesa); https:// www.encj.eu/images/stories/pdf/factsheets/italy_cpga.pdf (administrativā tiesa).

${ }_{20}$ Pieejams: https://www.encj.eu/images/stories/pdf/factsheets/cgpj_spain.pdf.

21 Pieejams: https://www.encj.eu/images/stories/pdf/factsheets/csm_portugal.pdf.
} 
procesā uz Ministru kabinetu, bet tieši uz Saeimu, lūdzot Juridisko komisiju pieņemt tās priekšlikumus kā savus.

No vienas puses, šāda prakse ir pozitīvi vērtējama no varu līdzsvara viedokḷa, ierobežojot izpildvaras ietekmi. Tomēr šāds process ir îsāks laikā un tādējādi dal̦ēji apdraud kvalitatīvu konsultāciju iespēju. Esošā regulējuma ietvaros risinājums būtu ikreizējas konsultācijas Tieslietu padomē, vēl pirms likumprojekts tiek izstrādāts un iesniegts Saeimā, kopā ar jau iedibināto praksi Tieslietu padomē saņemot likumprojektu no Saeimas viedokḷa paušanai pirms otrā lasījuma, pamatlasījuma. ${ }^{22}$

Tāpat būtu tālāk analizējama un paplašināma prakse likumā "Par tiesu varu" ietvert delegéjumus Tieslietu padomei noregulēt atsevišķus jautājumu lokus ar saviem lēmumiem, kā tas jau nesen noticis attiecībā uz tiesas priekšsēdētāju un viṇu vietnieku iecelšanas kārtību ${ }^{23}$ un tiesnešu kandidātu atlasi un apstiprināšanu. ${ }^{24}$

Likumdošanas iniciatīvas tiesības Tieslietu padomei ir grūti iniciējams jautājums, jo prasītu Satversmes 65. panta grozījumus. Gadijumā, ja tas tomēr tiktu nopietni apsvērts (iespējams, vienlaikus ar pašas Tieslietu padomes ierakstǐšanu Satversmē, līdzìgi kā tas ir jau pieminēto ES dalībvalstu piemēros), formulējums varētu būt lìdzīgs kā Satversmes tiesas likuma ${ }^{25}$ 17. pantā ietvertais attiecībā uz Tieslietu padomes tiesībām iesniegt pieteikumu Satversmes tiesā - "likumā noteiktās kompetences ietvaros".

Tieslietu padomes lomas nostiprināšana likumdošanas procesā būtu nepieciešama arī tādēḷ, ka pārmērīga un dažreiz nekonsekventa pārējo varu lìdzdalība tieslietu sistēmas problēmu risināšanā savukārt noved pie tiesiskās nestabilitātes. Visai uzskatāmi to parāda vienkārši skaitḷi - kopš Tiesnešu disciplinārās atbildỉbas likuma pieņemšanas Saeimā 1994. gada 27. oktobrī tam bijušas 7 grozījumu paketes, savukārt likums "Par tiesu varu" kopš tā pieṇemšanas 1992. gada 15. decembrī ir grozìts 41 reizi.

Atskatoties uz jau pieminēto Tiesiskās vides pilnveides komisijas ziņojumu, jākonstatē, ka liela daḷa tās ieteikumu par kompetenču piešķiršanu Tieslietu padomei ir izpildīti. Īpaši būtiska ir tiesneša karjeras jautājumu nodošana Tieslietu padomes kompetencē. Te visai precīzi realizējušās arī agrākas tieslietu ekspertu rekomendācijas. ${ }^{26}$

22 Saskaṇā ar Saeimas kārtības rulli pirmajā lasījumā Saeima debatē par likumprojekta principiem, savukārt trešajā - izskata tikai tos pantus, par kuriem iesniegti priekšlikumi. Otrais lasījums ir vienīgais, kurā tiek skatīts viss likuma teksts kopumā, likumprojektu izskatot pa pantiem. Sk. attiecīgi Saeimas kārtības rullıa 88., 99. un 110. pantu.

${ }^{23}$ Likuma "Par tiesu varu" 33. un 40. pants. Pieejams: http://www.at.gov.lv/files/uploads/files/9_Tieslietu_padome/Dokumenti/Tiesu\%20priekssedetaju\%20apstiprinasanas\%20kartiba.pdf.

${ }^{24}$ Likuma "Par tiesu varu" $54 .{ }^{1}$ pants, $54 .^{2}$ pants. Pati jaunā kārtība tika apstiprināta ar Tieslietu padomes 15.04.2020. lēmumu Nr. 20 un ir atrodama Tieslietu padomes mājaslapā. Pieejams: http://www.at.gov. lv/files/uploads/files/9_Tieslietu_padome/Dokumenti/TP_lemums_nr_20_2020_ar_pielik_1.pdf.

${ }^{25}$ Latvijas Vēstnesis, 14.06.1996., Nr. 103. Konsolidētā versija pieejama: https://likumi.lv/ta/id/63354satversmes-tiesas-likums.

26 Osipova S., Strupišs A., Rieba A. Tiesu varas neatkarības un efektivitātes palielināšanas un nostiprināšanas rezerves. Jurista Vārds, 09.03.2010., Nr. 10 (605). Pieejams: https://juristavards.lv/doc/206150-tiesuvaras-neatkaribas-un-efektivitates-palielinasanas-un-nostiprinasanas-rezerves/. 
Savukārt komisijas ieteikumi par Tieslietu padomes lomu tiesnešu kvalifikācijas vērtēšanas un disciplināratbildības jomās ${ }^{27}$ visdrīzāk paliks nerealizēti konkrētāk par to risināšanu tiesībpolitiskā un likumprojektu apspriešanas jomāa. ${ }^{28}$

Tomēr jau pašlaik funkcionāla sasaiste pastāv ar visām trim tiesnešu pašpārvaldes institūcijām - Tieslietu padome apstiprina TKK un TĒK reglamentus un visas trīs pašpārvaldes institūcijas tiek uzaicinātas piedalīties un izteikt savu viedokli, Tieslietu padomei izskatot to kompetencē esošos jautājumus, kā arī pašas vēršas pie Tieslietu padomes.

Nākotnē, nostiprinot Tieslietu padomi institucionāli un, vēlams, nododot tās pārraudzībā Tiesu administrāciju, ${ }^{29}$ padzilı̣nātos arī tās ikdienas saikne ar tiesnešu pašpārvaldes institūcijām, kuru darbību nodrošina Tiesu administrācija.

\section{Secinājumi}

1. Četru iepriekš aprakstīto institūciju darbība kopumā nodrošina visu tiesneša atbildības aspektu realizāciju.

2. Tieslietu sistēmas paškontroles sistēma eksistē un strādā, un informācija par tās darbību ir publiski pieejama likuma noteiktajās robežās.

3. Šìs atbildỉbas standarts un tiesnešu pašpārvaldes institūciju stingrība tā garantēšanā ir pastāvīgi analizējams jautājums, tomēr jāatceras, ka šobrīd gan tiesnešu pašpārvaldes institūcijas, gan Tieslietu padome strādā kā periodiskas sanāksmes, nevis kā pastāvīgas institūcijas. Tādēḷ to darba tālāka kvalitatīva izaugsme iespējama vien caur institucionalizāciju.

4. Vispirms šì institucionālās nostiprināšanas nepieciešamība attiecas uz Tieslietu padomi un uz Tiesnešu kvalifikācijas kolēgiju, kurai vienīgajai no tiesnešu pašpārvaldes institūcijām ir prognozējams - un ievērojams - darba apjoms, pamatā saistībā ar regulārajiem profesionālās kvalifikācijas novērtēšanas cikliem. Šis process atkarīgs arī no likumdevēja un izpildvaras vēlmes iesaistīties tā risinājumā, jo prasa gan likuma grozijjumus, gan budžeta piešḳīumu.

5. Latvijā vēl vāji attīstīta visu triju valsts varas atzaru izpratne par kopīgu misiju, un to sadarbības nostiprināšana ir daudzu risinājumu avots. Sai sadarbībai jānodrošina gan tieslietu sistēmas stabilitāte, gan tās izaugsme. Savukārt pašas tieslietu sistēmas interesēs ir veidot un uzturēt standartus, kas ne vien neprasa, bet arī izslēdz abu pārējo varu pārmērīgu iejaukšanos tās funkcionēšanā.

27 Arī ziņojumā. Ibid.

${ }^{28}$ Kā tas redzams no Eiropas Tieslietu padomju asociācijas apkopotās informācijas par tās dalīborganizāciju kompetencēm, tiesnešu karjeras jautājumi (bet ne novērtēšana) ir vairuma valstu Tieslietu padomju kompetencē. Disciplināratbildības un ētikas jautājumus arī risina daudzas no tām, bet mazākā mērā. Valstu institucionālo un kompetences modeḷu apraksti atrodami ENCJ mājaslapā. Pieejams: https://www.encj.eu/members.

${ }^{29}$ Kā tas tika sākotnēji iecerēts, Tieslietu ministrija pirms iestāšanās ES izstrādāja likumprojektu “Tiesu iekārtas likums”, kuru 09.03.2004. iesniedza Saeimā E. Repšes valdība (vēstule Nr. 90/TA-488, reǵistrēta Saeimas kancelejā 10.03.2004. ar Nr. 1128), lūdzot likumprojektu atzìt par steidzamu, bet jau 17.03.2004. to atsauca I. Emša valdība (vēstule Nr. 111-1/10, registrēta Saeimas kancelejā 17.03.04. ar Nr. 1374), aizbildinoties ar nepieciešamību veikt papildu precizěšanu un saskaņošanu ar Eiropas Kopienas tiesību normām. Šajā likumprojektā tika paredzēts, ka Tieslietu padome īsteno valsts politiku un stratēgiju tiesu sistēmas attīstībā un tās darba pilnveidošanā, savukārt Tiesu administrācija, kuras nolikumu apstiprina Tieslietu padome, ir tiesu sistēmas iestāde, kuras mērḳis ir organizatoriski nodrošināt tiesu sistēmas darbu. Tā arī pilda Tieslietu padomes sekretariāta funkciju un citus pienākumus tās uzdevumā. 